\title{
Endoscopic Approach to Giant Bladder Stone in Patient With Orthotopic Urinary Diversion
}

\author{
Ortotopik Üriner Diversiyonlu Hastada Dev Mesane \\ Taşına Endoskopik Yaklaşım
}

Olgu Sunumu Case Report

Alındığı tarih: 01.03 .2019 Kabul tarihi: 27.04.2019 Online Yayın tarihi: 28.03.2020

Çağdaş Bildirici Health Sciences University, Tepecik Training and Research Hospital, Urology Clinic, Izmir, Turkey

cagdas_bildirici@hotmail.com ORCiD: 0000-0002-4220-8147

T. Süelözgen 0000-0003-0790-3926 Y.ö. illbey 0000-0002-1483-9160 Health Sciences University, Tepecik Training and Research Hospital, Urology Clinic, Izmir, Turkey

Cite as: Bildirici C, Suelozgen T, Illbey YO. Endoscopic approach to giant bladder stone in pascopic approach to giant bladder stone in pa-
tient with orthotopic urinary diversion. Tepecik Eğit. ve Araşt. Hast. Dergisi. 2020;30(1):100-3.

\author{
Çağdaş Bildirici $\odot$, Tufan Süelözgen $\odot$, Yusuf Özlem illbey $\odot$
}

\begin{abstract}
Urinary tract stone is a delayed and rare complication in patients with orthotopic urinary diversion. It can be detected incidentally or it may cause symptoms such as dysuria, gross hematuria, incontinence, recurrent urinary tract infection and suprapubic pain. The imaging modalities used in diagnosis and treatment methods are similar to the other stone diseases and the patients with orthotopic diversion require close follow-up and appropriate prophylaxis with regard to stone disease. In this article, we evaluated the management of a 62-year-old patient who underwent radical cystoprostatectomy and orthotopic diversion due to muscle-invasive bladder cancer 20 years ago and reapplied to our clinic with symptoms of a $6 \mathrm{~cm}$ stone in neobladder.
\end{abstract}

Keywords: Orthotopic urinary diversion, bladder stone, cystolithotripsy

ÖZ

Ortotopik diversiyon yapılan hastalarda üriner sistem taşı geç semptom olarak görülen komplikasyonlardandır. Insidental tespit edilebildiği gibi dizüri, gros hematüri, inkontinans tekrarlayan idrar yolu enfeksiyonu, suprapubik ağrı gibi semptomlar verebilir. Tanıda kullanılan görüntüleme yöntemleri ve tedavi diğer taş hastalarına benzer olup ortotopik diversiyonlu hastalarının taş hastalığı açısından takibi ve uygun profilaksisi gereklidir. Bu yazıda kliniğimize başvuran 62 yaşında, 20 sene önce kasa invaziv mesane kanseri nedeni ile radikal sistoprostatektomi ve ortotopik diversiyon yapılan ve neobladderda yaklaşık $6 \mathrm{~cm}$ boyutlu taş olan hastanın tedavisini ele aldık.

Anahtar kelimeler: Ortotopik üriner diversiyon, mesane taşı, sistolitotripsi

\section{INTRODUCTION}

Radical cystoprostatectomy with pelvic lymph node dissection is the standard treatment of muscle-invasive bladder cancer from the standpoint of long-term survival ${ }^{(1)}$. Ileal diversion or orthotopic diversion can be performed according to the patient's preference and operation conditions. Orthotopic urinary diversion is a method that can be applied in neurogenic bladder and congenital anomalies. Patients with orthotopic urinary diversion are at higher risk of stone forma- tion in bladder, ureter and renal collecting system, in comparison to the normal population ${ }^{(2)}$. Stone formation is multifactorial in continent diversion. Infections, metabolic factors, anatomical features, adherence to using clean intermittent catheterization (CIC) can be mentioned among these factors. Patients are often diagnosed incidentally. The most common symptoms are dysuria, incontinence, recurrent urinary tract infection, hematuria, suprapubic pain and pressure sensation, difficulties encountered during $\mathrm{CIC}$ and urination ${ }^{(3)}$. There (c) Telif hakkı T.C. Sağlık Bakanlı̆̆ı İzmir Tepecik Eğit. ve Araşt. Hastanesi. Logos Tıp Yayıncııık tarafindan yayınlanmaktadır. Bu dergide yayınlanan bütün makaleler Creative Commons Attf-GayriTicari 4.0 Uluslararası Lisansı ile lisanslanmıştır.

- (c) Copyright Association of Publication of the T.C. Ministry of Health İzmir Tepecik Education and Research Hospital. This journal published by Logos Medical Publishing. Licenced by Creative Commons Attribution-NonCommercial 4.0 International (CC BY-NC 4.0) 
are various treatment options for the patients who underwent continent diversion and developed urinary stones as is the case in normal population having urinary stones.

\section{CASE REPORT}

The patient was a 62-year-old male patient working in textile industry. He underwent open radical cystoprostatectomy + orthotopic urinary diversion because of bladder cancer in 1998. He remained asymptomatic for many years without using $\mathrm{ClC}$. He suffered from urinary incontinence in deep sleep at nights for the last 10 years. Recently, he applied to our outpatient clinic due to increased frequency of his complaints. He was not using $\mathrm{CIC}$ when he applied. Direct urinary system graphy (DUSG) showed an opacity of $66 \times 48 \mathrm{~mm}$ in size in the orthotopic bladder. Subsequent urinary ultrasonography (USG) revealed an echogenicity consistent with a $57 \mathrm{~mm}$-sized stone in the operated bladder. In the abdominal computed tomography (CT), a hyperdense appearance consistent with a $6 \mathrm{~cm}$-diameter stone was determined in the bladder inferiorly. Additionally, there were contour irregularities and septations in the bladder. Renal function tests of the patient were within normal limits, despite bilateral grade 2-3 hydroureteronephrosis (HUN). Creatinine and glomeruler filtration rate (GFR) were $1.2 \mathrm{mg} / \mathrm{dL}$ and $65.21 \mathrm{mg} / \mathrm{dL}$, respectively.

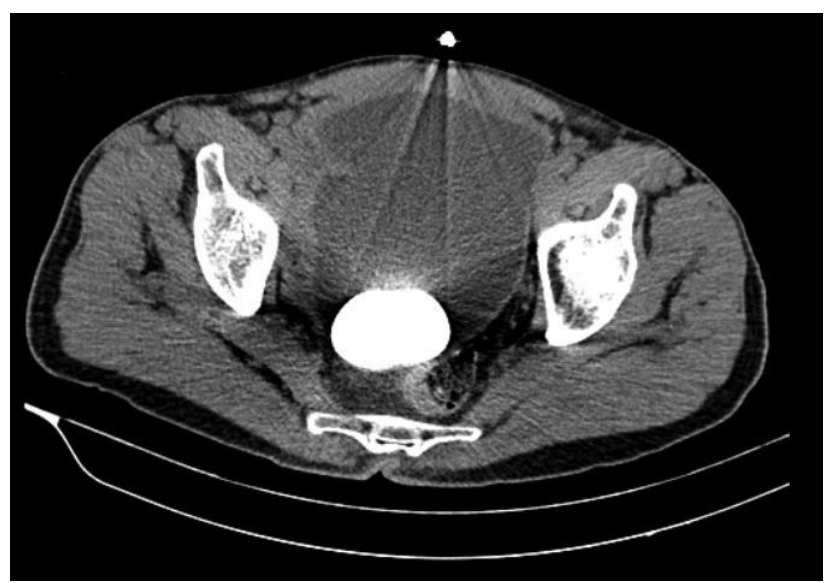

Figure 1.

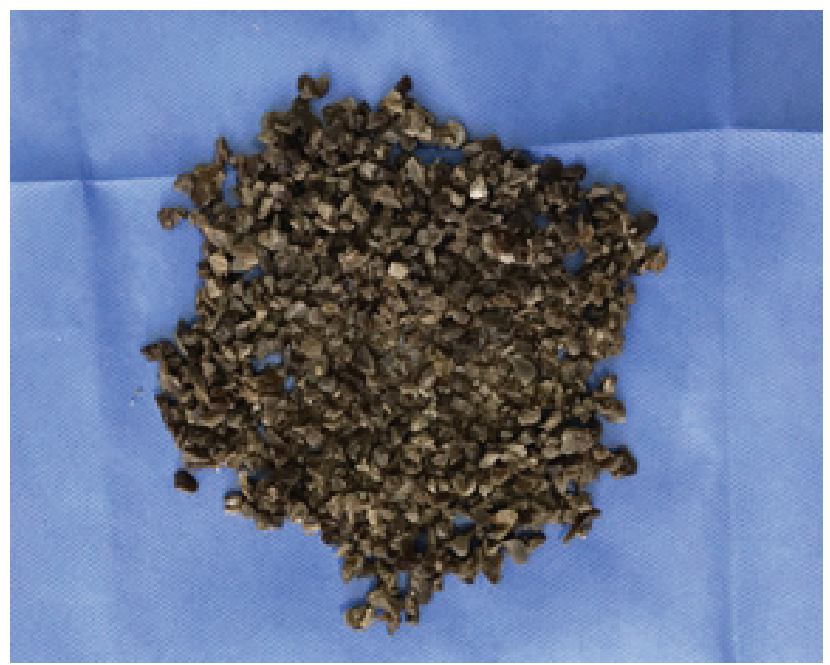

Figure 2.

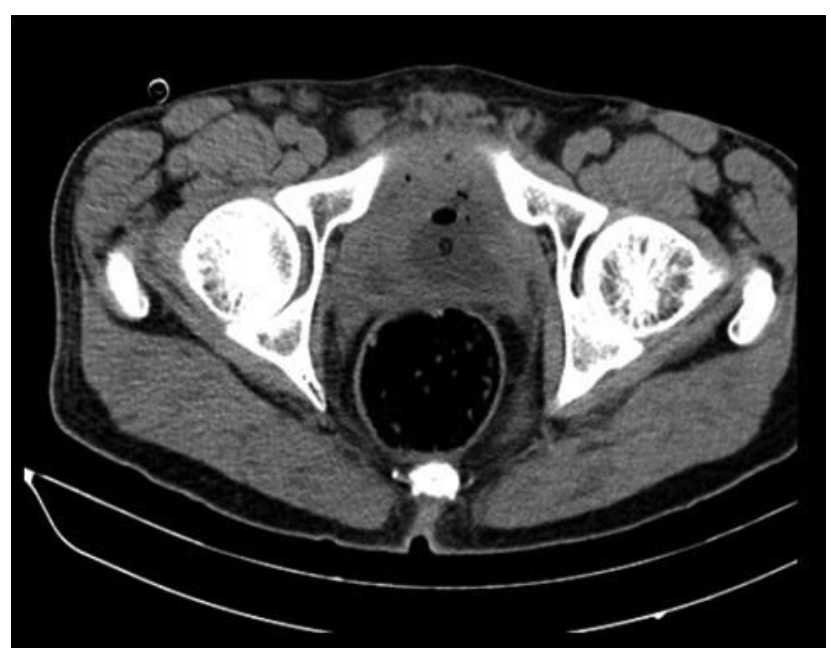

Figure 3.

Open stone surgery was not preferred because of the appearance of the neobladder wall structure, so endoscopic treatment was planned. The patient's bladder stone was treated in two sessions of endoscopic surgery (cystolithotripsy). After first operation control abdominal CT revealed the presence of residual stone. However, control abdominal CT after second operation any residual stones were not detected in the bladder.

\section{DISCUSSION}

The incidence of bladder stone formation in patients with continent urinary diversion is between \%2.9 
and $\% 12.9^{(4)}$. Although stone formation is generally associated with infection, nonetheless, metabolic factors, structural factors, surgical technique, materials used, non-use of $\mathrm{CIC}$ may be effective in stone formation as well ${ }^{(5,6)}$.

Urinary tract infections caused by urease-positive bacteria facilitate formation of urinary tract stones. Infection-induced stones are usually struvite, calcium ammonium phosphate, carbonate-apatite, magnesium ammonium phosphate stones. Calcium oxalate stones are encountered less likely ${ }^{(7)}$.

Metabolic factors cause stone formation, depending on the segment used for diversion. The length of the segment used, the origin of the segment, urine contact time, urine $\mathrm{pH}$ and urine content cause various metabolic changes ${ }^{(8)}$. The most frequent complication is metabolic acidosis ${ }^{(9)}$ which can result in hyperoxaluria, hypercalciuria, hyperphosphaturia, hypermagnesuria and hypocitraturia ${ }^{(10)}$. lleum is the most used segment while jejunum is the least used one, due to the high risk of related metabolic complications ${ }^{(9)}$.

Structural factors such as urinary reflux, chronic urinary dilatation, non-use of $\mathrm{CIC}$ or non-adherence to $\mathrm{CIC}$, and ureterointestinal strictures are also effective in stone formation ${ }^{(11)}$. During the operation, discharging the reservoir completely and not using stapled anastomosis should be kept in mind to prevent stone formation in patients undergoing continent diversion ${ }^{(6)}$.

Non-use of CIC as in our patient's case stands out among the probable causes of stone formation.

Patients with bladder stones due to continent diversion are usually detected incidentally. In symptomatic patients, dysuria, incontinence, recurrent urinary tract infection, gross hematuria, suprapubic pain and pressure sensation, difficulties in using $\mathrm{CIC}$ and during urination are common ${ }^{(3)}$. Our patient had a complaint of incontinence during sleep at night.
DUSG is the first method used for diagnosing the patients with orthotopic diversion. Complete abdominal USG and abdominal CT may provide more detailed information. Stone hardness can be determined by using abdominal $\mathrm{CT}{ }^{(12)}$. We also used these imaging methods in our patient sequentially and obtained sufficient information about the localization, size and hardness of the stone in the neobladder.

The treatment of urinary tract stones in the patients with continent diversion is similar to the approach for the general population. Oral hydration of the patient should be provided. Dietary regulation can be implemented. Bladder should be regularly evacuated by means of $\mathrm{CIC}$ in order to prevent stone formation. Urinary tract infection should be treated, if present. Urease inhibitors can be used for the treatment of struvite stones. Aluminum hydroxide, known to reduce phosphate absorption, can be used prophylactically ${ }^{(13)}$. Extracorporeal shock wave lithotripsy (ESWL), stone crushing using stone basket (The Trapezoid RX Wire guided Retrieval Basket), cystolithotripsy or open surgery (cystolithotomy) can be performed as surgical treatment ${ }^{(14)}$. If the patient had anti-incontinence or bladder neck reconstruction, then meticulous attention should be paid in endoscopic approach to conserve continence mechanism ${ }^{(15)}$. We planned to remove the bladder stone by cystolithotripsy in several sessions due to the damaged bladder structure of our patient.

Lifetime prophylactic treatment and follow-up is recommended in cases with formation of stones after urinary diversion. Patel and Bellman recommended annual examinations with DUSG as well as flexible endoscopy of the lower urinary tract (16). Stein et al. ${ }^{(17)}$ recommended serum creatinine and bicarbonate measurements and USG every 6 months during the first 4 years and annual pouch endoscopy after $5^{\text {th }}$ year. In the treatment scheme of Beiko and Razvi, metabolic evaluation and DUSG are recommended at the $3^{\text {rd }}$ month, routine urine analysis, urine culture and DUSG at the $6^{\text {th }}$ month, and routine 
urine analysis, urine culture, DUSG and USG at the $12^{\text {th }}$ month and annually afterwards. The recommended metabolic evaluation includes routine urinalysis, urine culture, urine volume, $\mathrm{pH}$, creatinine, sodium, calcium, magnesium, phosphate, oxalate, potassium, carbondioxide, and uric acid measurements in 24-hour urine samples, twice. If stone disease is associated with metabolic factors, annual metabolic evaluation is required ${ }^{(7)}$.

\section{CONCLUSION}

Stone formation is an important long- term complication in patients with neobladder reconstruction and it is related to several variables. These patients should be provided with appropriate prophylaxis to prevent stone formation and followed up closely. Medical treatment should be provided first if there is an underlying infection and then surgical treatment should be implemented by endoscopic methods, and finally, if they fail, open surgical methods should be performed. Patients whose treatment is complete should be routinely screened for urine and blood parameters and by imaging methods against new stone formation.

\section{Conflict of Interest: None.}

Informed Consent: Received.

\section{REFERENCES}

1. Stein JP, Lieskovsky G, Cote R, et al.Radical cystectomy in the treatment of invasive bladder cancer: long term results in 1,054 patients. J Clin Oncol. 2001;19(3):666-75. [CrossRef]
2. Gerharz EW, Turner WH, Kälble T, Woodhouse CR. Metabolic and functional consequences of urinary reconstruction with bowel. BJU Int. 2003 Jan;91(2):143-9. [CrossRef]

3. Terai A, Arai $Y$, Kawakita M, et al. Effect of urinary intestinal diversion on urinary risk factors for urolithiasis. J Urol. 1995;153:37-41. [CrossRef]

4. erai A, Ueda T, Kakehi Y, et al. Urinary calculi as a late complication of the Indiana continent urinary diversion: comparison with the Kock pouch procedure. J Urol. 1996;155:65-8. [CrossRef]

5. Assimos DG. Nephrolithiasis in patients with urinary diversion. J Urol. 1996 Jan;155:69-70. 10. [CrossRef]

6. Brough RJ, O’Flynn KJ, Fishwick J, Gough DH. Bladder washout and stone formation in pediatric enterocystoplasty. Eur Urol 1998;33:500-2. [CrossRef]

7. Beiko DT, Razvi H. Stones in urinary diversions: update on medical and surgical issues. Curr Opin Urol. 2002 Jul;12(4):297-303. [CrossRef]

8. McDougal WS. Metabolic complications of urinary intestinal diversion. J Urol. 1992;147:1199-208. [CrossRef]

9. Razvi HA, Martin TV, Sosa ER, Vaughan ED Jr. Endourologic management of complications of urinary intestinal diversions. AUA Update Series. 1996;15(Lesson 22):174-9.

10. Patel H, Bellman GC. Special considerations in the endourologic management of stones in continent urinary reservoirs. J Endourol. 1995;9(3):249-54. [CrossRef]

11. Drach GW. Secondary and miscellaneous urolithiasis: medications, urinary diversions, and foreign bodies. Urol Clin North Am. 2000;27:269-73. [CrossRef]

12. Myers MT, Elder JS, Sivit CJ, Applegate KE. Unenhanced helical CT in the evaluation of the urinary tract in children and young adults following urinary tract reconstruction: comparison with sonography. Pediatr Radiol. 2001;31:135-9. [CrossRef]

13. Brock WA, Nachtsheim DA, Parsons CL. Hemiacidrin irrigation of renal pelvic calculi in patients with ileal conduit urinary diversion. J Urol. 1980;123:345-7. [CrossRef]

14. McDougal WS, Kock MO. Effect of sulfate on calcium and magnesium homeostasis following urinary diversion. Kidney Int. 1989;35:105-15. [CrossRef]

15. Poulsen AL, Steven K. Acid-base metabolism after bladder substitution with ileal urethral Kock reservoir. $\mathrm{Br} J$ Urol. 1996;78:47-53. [CrossRef]

16. Patel H, Bellman GC. Special considerations in the endourologic management of stones in continent reservoirs. J Endourol. 1995;9:249-54. [CrossRef]

17. Stein R, Fisch M, Thüroff JW. Ureterosigmoidostomy, conduit and continent urinary diversion. Eur Urol. 1999;36:266-76. [CrossRef] 